ARTICLE

DOI: 10.1057/s41599-017-0051-y

\title{
Imagining a future without dementia: fictions of regeneration and the crises of work and sustainability
}

\author{
Lucy Burke (i) ${ }^{1}$
}

\begin{abstract}
This essay explores the kind of cultural and ideological work effected by the concept of dementia in contemporary popular culture in the global north through a critical reading of three 'genre' texts: Renny Harlin's action movie meets sci-fi, Deep Blue Sea (1999), Vernor Vinge's speculative fiction Rainbows End (2007) and Rupert Wyatt's sci-fi drama, Rise of the Planet of the Apes (2011), all of which engage with the possibility of neural regeneration and a cure for dementia. Dominant epistemologies of dementia and ageing often focus on the potentially unsustainable social and economic burden presented by an ageing population and the obligation to meet the needs of older people living with impairments. Exploring the articulation of these economic and political arguments alongside an analysis of the promissory discourses of bio-gerontology and neuroscience, this essay considers the ways in which dementia has emerged as an over-determined point of tangency upon which particular ideas about ageing, mortality, human value, sustainability and futurity are played out. The analysis of the cultural texts presented here exposes the limits of market and individual oriented responses to dementia and ageing within the broader context of what Nick Srnicek and Alex Williams have described as the 'emerging crisis of work and surplus populations'. This paper argues that an exploration of the ideological fault-lines, imaginary resolutions and forms of wish fulfilment that emerge in the films and novel, enable us to identify the ideological limitations of the neoliberal discourses that circumscribe the ways in which we currently understand dementia and our imaginative investments in the promise of its cure.
\end{abstract}

\footnotetext{
${ }^{1}$ Department of English, Manchester Metropolitan University, Manchester, UK. Correspondence and requests for materials should be addressed to L.B. (email: I.burke@mmu.ac.uk)
} 


\section{Introduction}

$t$ the centre of this essay is an argument about the kind of cultural and ideological work effected by the concept of dementia in contemporary popular culture in the global north. Without diminishing the challenges that living with dementia presents nor the importance of neuroscientific and medical research in this field, my focus here is on the ways in which the contemporary meanings of this complex syndrome (George et al., 2011) emerge at the intersection of science, politics, economics, bioethics and culture. This is to foreground the ways in which dementia operates as an ideologically freighted category, utilised and put to work to further particular political and ethical debates as much as it describes a set of pathological processes, a range of symptoms and a lived, embodied experience. (Burke, 2015, pp 9-10)

In what follows, I explore the role played by current epistemologies of dementia in relation to ideas about life extension, regeneration and sustainability and the economic and ideological frameworks that underpin them. As Céline Lafontaine argues, in contemporary cultural discourse ageing has become a 'crisis' that "cannot be separated from the emergence of a bioeconomy based on the pharmaceutical industry, genetic engineering and the development of biomedical research as a whole"(Lafontaine, 2009, p 56). As a condition that tests the limits of current biomedical research, dementia plays a crucial role in the attribution of ageing as an intractable social and economic problem particularly for the economies of the global north. It is its role as an over-determined point of tangency upon which particular ideas about ageing, regeneration, human value, sustainability and futurity are played out that interests me here.

There are only a few literary and cinematic texts that explicitly address the possibilities of neural regeneration or cure in relation to the kind of cognitive impairment associated with dementia. ${ }^{1}$ However, I would argue that these texts illuminate the ideological limitations of the dominant paradigms through which we currently know, understand and approach the challenges with which dementia as a predominantly age-related condition presents us. This essay addresses these issues through a critical comparison of three popular cultural 'genre' texts: Renny Harlin's action movie meets sci-fi, Deep Blue Sea (Harlin, 1999), Vernor Vinge's speculative fiction Rainbows End (Vinge, 2007) and Rupert Wyatt's Rise of the Planet of the Apes (Wyatt, 2011).

Hollywood blockbusters and popular science fiction, like all cultural practices, are born out of determinate historical situations. From a materialist standpoint, such cultural productions are both shaped by, and attempts to shape or resolve the historical questions with which they engage. These imaginary or cultural 'resolutions' to real social problems (Jameson, 2013) operate not just in the raw historical material or content of the film but also in the narrative structure, stylistic innovations and cultural form of any given text. My reading of these texts draws attention to ideological "faultlines" (Sinfield, 1992) that cannot be directly expressed in some of the most culturally powerful and ideologically persuasive articulations of dementia, ageing and biological regeneration. Read against the grain, these fictional narratives reveal the systemic violence, contradictions and pressures that underpin the kind of economic and political arguments that ask us to imagine that a future without dementia is the answer to the social and economic challenges presented by an ageing population. However, before I progress to an analysis of these texts, I first want to provide some more context regarding the historical developments to which they respond.

\section{Ageing as the enemy within: dementia and the biomedical imaginary today}

Writing in the context of the medicalisation of dementia in the twentieth century, Sharon Kaufman describes Alzheimer's as a "modern form of life itself" and details the capacity of diagnosis and the medical apparatus to transform "living beings" into victims, patients, and research subjects with a degenerative brain disease (Kaufman, 2006, pp 24-25). As many scholars have noted, dementia emerges into public discourse in the late twentieth century as an imminent crisis of epidemic proportions, the site upon which new bodies and subjects are materialised and upon which ethical debates around care, personhood and the value of some lives over others are harnessed and played out. (See, for example, Fleischer, 1999; Kitwood, 1989; Kitwood, 1990; Leibing and Cohen, 2006; Shakespeare et al., 2017; Singer, 1996). Kaufman identifies the dementia victim, patient and research subject but we can also add the dementia expert, the dementia activist, the 'dementia friend' along with the panoply of private enterprises, third sector, cultural and community organisations that have emerged in the wake of the so-called "Alzheimer's epidemic" (Lin and Lewis, 2015).

The biomedicalisation of dementia occurs in tandem with a powerful imaginative investment in the potential of scientific research to enable us to defeat age-related illnesses and even, for some, to evade age-related mortality. This is manifest both in the biologisation of age-related conditions such as dementia and also in the biologisation of ageing itself as witnessed in the emergence of the sub-disciplinary fields of theoretical, molecular, biogerontology and cyto-gerontology (Kirkwood, 2002; Kirkwood, 2005; Kirkwood and Cremer, 1982; Moreira and Palladino, 2009). One of the major and rather controversial examples of this type of development is Aubrey D.N.J.de Grey's proposed 'strategies for engineered negligible senescence' (SENS). De Grey's ultimate aim with SENS is to extend life indefinitely (Grey et al., 2002) on the basis of the potential of telomerase, allotropic mitochondrialcoded proteins and marker-tagged toxins to combat the "damage" and "junk" of the aging process (Zealley and De Grey, 2013). The reconfiguration of ageing (Moreira and Palladino, 2008) as a complex biological process that biomedical research will ultimately enable us to resist is, as Melinda Cooper has argued, sustained by the promises of stem-cell research and the identification of cell lines with the capacity "to reproduce themselves indefinitely" (Cooper, 2011, p 129). As the bio-gerontologist Tom Kirkwood notes, "to understand the cell and molecular basis of aging is to unravel the multiplicity of mechanisms causing damage to accumulate and the complex array of systems working to keep damage at bay" (Kirkwood, 2005, p 437).

Many scientists such as Kirkwood caution against the claim that current scientific research has the potential to defeat agerelated mortality (Moreira and Palladino, 2008; Warner et al., 2005). For instance, de Grey's aim to extend life indefinitely through 'strategies for engineered negligible senescence' has been described by a group of bio-gerontologists (including Kirkwood) as "so far from plausible that it commands no respect at all within the scientific community" (Warner et al., 2005, p 1006). However, at the level of popular culture, the growing traction of research on life extension points to "a new social configuration whereby the avoidance of ageing and the pursuit of immortality are becoming normatively binding" (Moreira and Palladino, 2008, p 22). This configuration is exemplified by the proliferation of crowd-funded biotechs, non-profit organisations and foundations such as The Methusalah (Methuselah Foundation) and also de Grey's SENS Research Foundation (Sens Research Foundation: reimagine aging). All of the above organisations invest, largely uncritically 
both financially and ideologically, in the potential of scientific research to prevent and forestall the genetic, environmental and cellular processes that characterise ageing and which contribute to the age-related conditions that cause the majority of our deaths. For example, the ELPIs Foundation for Indefinite Lifespans describes its mission "to research, discuss and describe strategies that may lead to the abolition of age-related degeneration and involuntary death due to ageing" (The ELPIs Foundation for Indefinite Lifespans) and The Brain Preservation Foundation argues for brain preservation research and technologies on the basis that we may soon be able to revivify our minds and memories:

... with the ever quickening pace of science and technology more of us are realising that death will not be a part of the human condition forever. Our great-grandchildren may not know traditional death at all; ours may be one of the very last generations to cower under its looming shadow. The perfection of brain preservation technology represents today's best chance at reaching that future world. (The Brain Preservation Foundation, 2017)

These online organisations typically combine extracts from scientific papers with optimistic extrapolations of recent research and invitations to donate to and support their endeavours to defeat senescence. "Aging is an enemy", the Fight Aging website tells us, "So fight it!" (Fight Aging!, 2017). This kind of popular iteration of bio-gerontology is an essentially promissory discourse, the realisation of which is presented as wholly contingent upon our investment in the promise and in the belief that scientific research alone will enable us to reinvent ourselves and embrace an indefinite future. However, it is important to underline the extent to which the force and dynamism of this promise operates primarily at the level of the imagination. It engages us at an affective level rather than primarily rational level and thus cannot be contained or dismissed purely with reference to scientific epistemologies. Its status as fantastical or implausible nonsense has little bearing on its force and appeal. Indeed, it is precisely the appropriation of this appeal as the motivation for the investment of financial and intellectual capital that serves as a central component in the confident predictions of figures such as de Grey as to the successful realisation of the dream of biological regeneration. De Grey's approach to criticism of his scientific claims is essentially to present his detractors as suffering from both a failure of will and imagination (Grey, 2006a, b).

As this indicates, the biomedicalisation of both dementia and ageing has a number of consequences, not least in opening up the possibility that a condition that was previously associated with ageing might be cured, that neurological damage might be reversed and that neural cells might be regenerated. This possibility is precariously reinforced by the increasing attention in the scientific community to modifiable life style factors and risk prevention in relation to dementia (Kivipelto et al., 2005; Kivipelto et al., 2013; Ritchie et al., 2010). However, it is important to note that the reporting of this research in the media consistently elides the distinctions between the different illnesses that cause dementia. This serves to constitute what is in reality a complex and unknowable syndrome as a distinct and singular entity thus blurring the distinctions between mild and major cognitive disorders, vascular dementia and Alzheimer's and so on (George et al., 2011). The failure to differentiate between conditions for which preventative action may be possible, and those for which it is not, produces a set of pressures on the individual peculiar to contemporary global capitalism. The assertion of individual responsibility alongside the essential powerlessness of the individual to prevent certain dementias arguably reproduces the kind of modulation between hope and hopelessness, panic and the possibility of taking control that characterises the risk/security nexus that structures contemporary cultural responses to a range of threats from terrorism and paedophilia, to political justifications of austerity (Agamben and Emcke, 2001; Furedi, 2006). In other words, the notion that we must take action to protect ourselves, modify our behaviour, maintain constant vigilance and simultaneously manage our own anxiety levels about the consequences of ageing itself operates as a regulatory or disciplinary mechanism the effectivity of which arguably rests on its inherently contradictory quality. Its power lies in the impossible injunction to control the uncontrollable or to take responsibility for an unknowable, contingent future.

\section{Dementia now! Ideologies of crisis and disaster in the era of late capitalism}

At a political and governmental level, the biomedicalisation of dementia has facilitated an increasingly catastrophizing discourse. This posits the projected societal and economic costs of dementia care as an unmanageable and unsustainable burden intrinsic to the nature of the condition itself rather than to the ways in which we might manage care, organise our lives, conceive of our communitarian responsibilities to each other or even embrace the possibility of living and dying well with an impairment. The ubiquitous use of the language of natural disaster in stock phrases such as the "silver tsunami" or figuration of dementia as a rampant epidemic reinforce the alignment of a particular way of thinking about dementia with the natural world (Peel, 2014; Zeilig, 2013). This kind of rhetoric that insistently naturalises the notion of crisis suggests that our experience of dementia can somehow be abstracted from history and from the epistemological frameworks and ideological and political pressures that produce it as a particular kind of problem at a particular historical conjuncture. Reframed in the language of ecological crisis, dementia is posited as a condition whose effects and impact are socially and economically unsustainable. In a discourse that mirrors debates around limited natural resource and environmental crisis, the corollary of this type of approach is that it is becoming increasingly difficult to untether dementia as an agerelated condition from broader questions of resource and economic sustainability. It is interesting to note, however, that whilst dementia and ageing are subjected to this kind of economic evaluation on the grounds of the societal threat they apparently pose, neoliberal responses to climate change are characterised by a reluctance to intervene or acknowledge the role of unregulated consumer capitalism in environmental destruction (Monbiot, 2016).

As Jérôme Pélissier has argued many socio-economic studies posit ageing as a contributory factor in economic stagnation and regression (Pellissier, 2007). Underpinned by a narrowly defined conception of human value as the capacity to contribute to the production of surplus value through wage labour and consumerism, this view of ageing and more particularly of ageing with an impairment as essentially unproductive, burdensome and therefore value-less saturates popular cultural discourses. It is not incidental that the presentation of dementia as a catastrophic crisis in waiting has intensified since the financial crisis of 2008 in tandem with the rhetoric of austerity deployed to justify the dismantling of the welfare state and the reduction of illness and disability to questions of cost, burden and economic sustainability.

We can certainly see a correlation between ageing and impairment in later life and economic burden in the rhetoric of the anti-ageing movement and the online biosocial (Rabinow, 2007) activism of groups such as Fight Aging! In a section of their website entitled 'What are the costs and consequences of aging?, 
the focus is explicitly on the costs and consequences for economic productivity:

The overwhelming majority of all medical expenditure goes towards treating the consequences of aging or providing palliative care for the aged. Further, there is an enormous opportunity cost to aging: those who become frail and unable to work might have otherwise gone on to continue earning and creating value. The amounts involved are staggering: the cost of the most common chronic medical conditions in the US amounts to $\$ 280$ billion in expenditures and $\$ 1$ trillion in lost productivity each and every year. The overwhelming majority of that is due to aging. (Fight Aging!, 2017)

For the main part, the rhetoric of Fight Aging! interpellates its website visitors as individuals motivated by a personal investment in life extension taking the obviousness of immortality as a life goal as read. The website includes reminders of the importance of "regular exercise and the practice of calorie restriction with optimal nutrition." These reminders combine the familiar late capitalist emphasis on individual responsibility for health and wellbeing (Ayo, 2012; Galvin, 2002) with the idea that ageing and impairment are intolerable outrages that it is within the scope of medical research to eradicate because 'we' do not want to get old or to become frail and dependent. Crucially, at the heart of all this is an invitation literally to buy into the fight against ageing and to donate to de Grey's SENS Research Foundation as "no other organisation is doing as much to ensure that rejuvenation therapies will be developed" (Fight Aging!, 2017).

This kind of approach is entirely continuous with the broader privileging of the morally responsible, independent and implicitly able-bodied individual in neoliberal concepts of citizenship (Harvey, 2007; Turner, 2008, p 152). Highly critical of the regulatory powers of the US Food and Drug Administration, Fight Aging! pursues a small state, low regulation agenda as the best way to develop, trial and make available anti-ageing interventions. The ostensibly socially, culturally and economically abstracted human subject of anti-ageing research thus returns our gaze in the form of the affluent, informed and self-interested US citizen. There is no mention of the geopolitical, social or ethical implications of the endeavour to fight ageing. Nor is there any engagement with the broader economic context in which this research emerges, specifically in relation to the emergence of an ever-expanding and increasingly precarious surplus population, displaced from traditional jobs by globalisation, automation and A.I (Davis, 2006; Dyer-Witheford, 2010; Gabbard, 2008; Srnicek and Williams, 2015). Instead, there is an injunction to invest in a range of private initiatives in order to realise a dream of biological regeneration that is only conceivable for the wealthy.

In a sense, what we can begin to identify here is a particular and potentially constitutive contradiction at the heart of this enmeshing of anti-aging initiatives and investments in research to cure dementia with governmental and economic imperatives. Dementia re-cast as an epidemic or generational threat becomes a site of condensation wherein some of the key paradoxes of the current commodification of social life, or even life itself, are played out. Thus the invocation of a dementia as the locus of an imminent and catastrophic threat also sets the scene for a series of market interventions or speculative investment opportunities in anti-aging research. The threat of economic collapse predicated on the notion of the provision of care for older people with dementia as an unsustainable burden simultaneously serves to reawaken the life powers of the non-human in the structure and logic of capital. To invoke the suggestive words of thinkers as diverse as Naomi Klein (Klein, 2007) and Slavoj Žižek (Žižek, 2010), the imagination and discourses of disaster, epidemic, crisis, or even apocalyptic end times become a space within which the logic of capital can paradoxically re-imagine and re-enthuse the circuits of production and the endless re-valorisation of surplus value. In the case of the "Alzheimer's epidemic", the assertion of imminent disaster serves as the rationale for the kind of "crisis exploitation' that Klein describes as the 'shock doctrine' which is, for her, the ideological modus operandi of neoliberalism. Persistently described as catastrophic threat and unsustainable burden, dominant cultural representations of dementia associate the condition with the worse kind of aging (vulnerable, dependent, fragile) and present it as the greatest potential drain on economic and emotional resources.

It is in this context that imagining a future without dementia holds such an affective sway in the cultural and political imaginary and in which I want to explore the ideological implications and imaginative renderings of the promise of 'neural regeneration' and an Alzheimer's cure in two Hollywood blockbusters and one work of speculative fiction. One of my key concerns in what follows is to highlight the way in which the contradictions and silences in the following texts enable us to envision a critique of certain market-led assumptions about dementia and ageing and to address the limits of these ways of thinking about and evaluating life.

\section{"Deep blue sea is about giant sharks eating people"}

Renny Harlin's film Deep Blue Sea (1999) was released on the cusp of the millennium and at the beginning of a period characterised by increasingly apocalyptic projections of an imminent 'dementia crisis' in the global north (Jeste et al., 1999; Macdonald and Cooper, 2006; Nathan, 2000). The film imagines the consequences of a scientist's endeavour to find a cure for Alzheimer's disease and in many respects exemplifies what Fredric Jameson terms the "repetitive volatilisation" of mass culture (Jameson, 1979, p 27). A less than subtle combination of familiar texts, types and tropes, an eminently predictable disaster movie narrative is played out via the reworking of elements of Frankenstein (Shelley, 2014) and Spielberg (1975) and with passing visual references to the submarines of Jules Verne and the mothership in Scott (1979). As one of the blameless yet doomed characters presciently notes "living below is like living in space, you don't get room for mistakes". The narrative is also punctuated with stock comedic interludes provided by LL Cool J's Preacher, the cook at the deepsea research facility, Aquatica, at which all but two short scenes of the film are located. As Ian Nathan noted in his review in Empire (2000), the film offers "a dynamic, often thrilling mix of dumbarse horror-disaster movie staples and borderline parody" (Nathan, 2000).

The story unfolds over a weekend at the research facility in which the beautiful if emotionally contained English scientist Dr. Susan McAlester (played by Saffron Burrows) finally achieves her ambition to re-awaken Alzheimer's damaged neurons from what we later learn to be the genetically enhanced brains cells harvested from a 'super shark'. McAlester is driven to conduct this research having personal experience of losing her father to Alzheimer's disease. She conducts her experiment in the company of the CEO of Chimera Pharmaceuticals, Russell Franklin (Samuel L Jackson, who it later transpires cannibalised two of the seven survivors of a plane crash in the alps), her research team, Jim Whitlock, Tom Scoggins and Janice Higgins, and the muscular (and heroic) allAmerican-shark-wrangler-with-a-past, Carter Blake. Conveniently for the narrative at least, all other employees bar the instantly expendable Brenda Kerns in the communication tower, leave the facility for the weekend, thus avoiding the sudden and unexpected storm one would logically expect to follow an act of scientific hubris and the super shark revenge that ensues. At the 
end of the film only two of the eight main characters, Preacher and Carter, remain. Susan McAlester sacrifices herself to save both them and the wider world by using herself as bait to prevent the shark from making its escape into the deep blue sea.

McAlester's successful reinvigoration of cells damaged by Alzheimer's directly recalls the spark of electricity that reanimates the stitched together body parts of Frankenstein's monster. "What you are looking for here" she notes, "is lightening in a bottle. Neurons are becoming hyper osmotic. They are firing". However, unlike Shelley's story, the cosmological revenge meted out as a consequence of McAlester's act of Promethean arrogance is articulated with a Christian, mid-western and antiintellectual sensibility. In contrast to the film's other key inter-text Jaws, in which the geeky technocratic scientist survives alongside the police, thus allegorising what Jameson describes as "an alliance between the forces of law and order and the new technocracy of the multinational corporations" (Jameson, 1979, p 144), in Deep Blue Sea, the only characters that remain are the comedic figure Preacher (who uses his crucifix as a dagger when he is attacked by the shark) and Carter whose sparse and blunt conversation is aligned with his physical strength and bravery.

In this respect, the film's crude morality tale about the dangers of neuroscientific research and genetic modification is articulated alongside a deeply conservative notion of America that ultimately plays out as a form of paralysis or temporal arrest. The film allegorises the eradication of the forces of capitalist speculation (in the form of Russell Franklin, millionaire CEO and cannibal of the vulnerable), of scientific research (destroyed by the elemental forces of fire and water), and of the scientists themselves. Even the tentative romance between Carter and McAlester is sacrificed in the name of male friendship and the expunging of the assertive, female intellectual (who finally learns the error of her ways and does everyone a favour by being consumed by her monstrous progeny). In this sense, the story plays out the systematic erasure of its original conditions of existence- the sharks, the science, the scientists, the project and the facility are all destroyed in the end as if they had never been. We are thus left in a deracinated, dehistoricised present. The two, now unemployed, men lie on what remains of the research facility in the middle of an empty ocean. The cost of survival is unemployment and the absence of an imaginable future (the possibility of which may have been afforded symbolically by the realisation of the romance between McAlester and Carter). What begins as a film about neural regeneration thus concludes with an image of the redundant and non-productive; the two survivors exchange greetings with a boatful of relief workers returning to a job that no longer exists in a decimated location.

We can perhaps identify here an ironic reworking of the historical narrative of the displacement of human labour as a consequence of technological advance. As this suggests, the film is ultimately unable to imagine neural regeneration or an Alzheimer's cure. This is something that falls outside of the ethical, political and aesthetic frames with which it works. However, what is important is that the kind of Bible-belt, mid-American conservative pleasures that are attached to the eradication of science and the overcoming of the Leviathan are articulated with an assertion of historical crisis in which the working community on Aquatica is left without women or work, or any means to reproduce itself. In a sense then, the film intimates that the real problem with regeneration resides in its relation to economic production and productivity.

The film here is remarkably prescient in its imagining of the conjoined crises of work and surplus humanity that currently beset us. In some senses, the trajectory of the narrative allegorises the kind of historical trajectory that Thomas Frank explores in What's the Matter with Kansas (Frank, 2007) in which blue collar workers paradoxically collude with the destructive forces of capitalism that are destroying their own life chances and communities. However, in its envisioning of the triumph of this kind of conservative yet ultimately self-sabotaging sensibility, the film presents us with a question that is implied but never addressed in all the calls for an Alzheimer's cure: if we are not to die of cancer or heart disease or dementia, how are we to die and how are we to live as older people in our ageing bodies? And if we are to imagine a future in which we evade ageing and impairment, how are we to sustain ourselves in a world in which the very technology that facilitates our longevity is bound up with the forms of automation and artificial intelligence that underpin the current crisis of work and which are implicated in the projected crisis of care as an insuperable social and economic burden? As Nick Srnicek and Alex Williams argue in Inventing the Future, the replacement of human labour with automation and artificial intelligence means that 'the future isn't working' quite literally because of the eradication of traditional jobs and forms of wage labour (Srnicek and Williams, 2015). This raises the question of how we are going to live and care for each other in a world in which ever growing numbers of people-not simply older people or those with dementia—are rendered economically redundant.

\section{The future isn't working?}

As I noted above, the emphasis in both current political rhetoric and the kind bio-gerontological activism promoted by Fight Aging! is on the necessity to cure age-related conditions such as dementia in order to increase productivity, address economic stagnation and ameliorate the burden of social care and health costs. However, what this cannot address are the broader implications of a future in which vast swathes of people (not simply older people living with impairments) will be rendered 'economically unproductive' as a structural consequence of the historical development of capitalism and the need to extract maximum surplus value for the lowest labour costs by replacing humans with machines. The kind of systemic transformation necessary to address the challenges of increasing longevity and the crises of work and sustainability for populations as a whole arguably requires a paradigmatic shift in the ways in which we organise our lives, our ways of working and the structures and practices of care.

If Deep Blue Sea ultimately resists the promises of regenerative medicine, albeit from the kind of conservative, anti-intellectual perspective currently lauded by Donald Trump, Vernor Vinge's speculative novel, Rainbows End (2007) foregrounds the difficulties we encounter in the imagination of a fully realised social totality in which dementia can be cured. Set in 2025 in San Diego California, it describes a very different world to that of the research facility in Deep Blue Sea. The world of the novel is one in which digital technology and artificial intelligence permeate every space and expression of human sociality and in which reality is augmented by virtual overlays manipulated by wearable interfaces and accessed via contact lenses with advanced retinal displays. The environment is subject to constant modification and variation, connectivity is virtual and both within and without the narrative, this gives rise to a constitutive ontological uncertainty as to the nature, material reality and motivation of particular characters. Thus, for example, the integrity of the grad student Zulfikar Sharif is violated by a computer virus and his avatar is alternately inhabited by a young girl, Miri, and the 'mysterious stranger' whose enigmatic presence and identity remains a conundrum throughout. One of the central protagonists of the novel, poet Robert Gu, is cured of his late stage Alzheimer's disease by the medical facility at University of California at San Francisco and rapidly restored to full health, although this comes at the 
price of the loss of his skills as a poet and like other older people in the novel, he is initially unable to access or utilise the technology around him. The plot unfolds around Robert's return to high school and his embroilment in a complex plot involving military intelligence and the mysterious, omniscient stranger who communicates with Robert via Zulfikar Sharif and an avatar in the form of a playful anthropomorphic rabbit.

Vinge's novel is replete with references to gaming interfaces, software and hardware, platforms and virtual reality but what the novel appears unable to imagine is either history or "work" in the sense of material reproduction. Technology is described and cures are posited but without explanation as to their provenance or development. For instance, in contrast to the quasi-scientific and mechanistic explanations of cellular regeneration in Deep Blue Sea, in Rainbow's End there is no real endeavour to describe the processes that underpin Robert's cure; neither the provenance of the cure in particular branches of medicine nor the mechanisms by which it works are explored. Previously recumbent cells are simply turned 'on'. As Robert's virtual health care provider notes:

Today we did your eyes. In a week or so we'll start reinforcing your peripheral nervous system." Reed laughed. "You know you've even got the skin and fat biochemistry that responds to Venn-Kurasawa treatments. (p 27)

However, most significantly, this is a world in which the forces of production are entirely elided. We encounter the security apparatus, virtual medical practitioners and educators and there are references to advertising executives, but there are no references to other forms of work or to productive labour. For instance, there are no references to the practices which enable the reproduction and circulation of technology or indeed the reproduction and circulation of food or material goods-the wearable technology, the furniture on which people sit and so on. We thus have 'ideological reproduction' cut loose from material production. This occlusion of labour is redolent of the effacement of the human and ecological damage wreaked in the production of the sleek, minimalist smart phone. The world that Vinge imagines is predicated on the abstraction of the potential of technology from its capitalist mediation and thus from the question of its impact upon the mass of humanity and the environment itself. There is no space in the text for an exploration of the broader implications of the longevity that technology facilitates.

In many ways, Vinge's novel encapsulates the problem, as Jameson puts it, of imagining the future as anything but "a monotonous repetition of what is already here" (Jameson, 2003, p 65). Rainbows End does not envisage a radically new world but the world in which the forces of capitalism have simply further infiltrated every sphere of life and in which a handful of silicon valley corporations continue to dominate human interaction. There is in this respect, no 'future' but simply the continuation of the 'self-same'. Regeneration in this context, is not aligned with the new or the transformative, but with the kind of chronic mode discussed by Eric Cazdyn, "a mode of time that cares little for terminality or acuteness but more for an undying present" and in which "the maintenance of the status quo becomes, if not quite our ultimate goal, what we will settle for" (Cazdyn, 2012, p 5). What my reading of the 'non said' or silences in the novel suggests then, is that this chronic mode precludes the development of a critical understanding the implications of regeneration in relation to human longevity and its impact upon productivity and modes of living and working. Despite being enmeshed with the logic of late capitalism in Vinge's text, this logic does not allow us even to articulate the social and economic impact of an ageing population; it simply passes over this question in silence. It is worth noting here that despite the contortions and complexities of the plot itself, in the final analysis, and at the novel's conclusion, nothing significant has occurred. In keeping with the historical and temporal arrest with which Deep Blue Sea concluded, the novel is also unable to imagine work and economic reproduction in a world in which dementia has been cured.

\section{Dementia and utopia in contemporary mass culture: Rise of the Planet of the Apes}

In his essay 'Reification and Utopia in Mass Culture' (Jameson, 1979), Fredric Jameson outlines a historical materialist approach to the critical analysis and evaluation of mass cultural texts. In what remains a highly influential and important essay, Jameson rejects the celebratory embrace of mass culture and the selfconsciously anti-elitist stance of some cultural studies scholarship but also challenges the outright "stigmatisation" (p 130) of the standardised and 'pseudo-individual' products of the 'culture industry' (Horkheimer and Adorno, 2001) at work in the writings of the Frankfurt School. Instead, he argues that we should view mass cultural practices such as Hollywood cinema "not as empty distraction or "mere" false consciousness, but rather as a transformational work on social and political anxieties and fantasies which must then have some effective presence in the mass cultural text in order subsequently to be managed or repressed" ( $p$ 141). He goes on to develop his thesis through a close reading of two major Hollywood franchises, Spielberg (1975) and The Godfather parts one and two (1972 and 1974). As my reading of the debates about ageing, employment, regeneration and futurity (or the lack of) in Deep Blue Sea and Rainbows End make clear, such an approach is still important for cultural and social analysis today. However, Jameson's exploration of these earlier Hollywood box-office record breakers also foregrounds the expression of a series of "unconscious ideological and utopian impulses" at work within the films ( $p$ 147). His essay concludes with a reiteration of a claim that underpins so much of his writing, namely that:

... all contemporary works of art-whether those of high culture and modernism or of mass cultural and commercial culture-have as their underlying impulse-albeit in what is often distorted and repressed, unconscious form-our deepest fantasies about the nature of social life, both as we live it now, and as we feel in our bones it ought rather to be lived. ( $\mathrm{p}$ 147)

Jameson's essay is now nearly forty years old, yet its recognition of the capacity of a materialist critical practice to illuminate the ways in which mass and commercial cultural texts serve to allegorise and express the major ideological tensions and anxieties with which we live remains compelling. Yet it is with Jameson's recognition of the potential of these texts to express utopian or socially transformative impulses that I want to turn to Rise of the Planet of the Apes and its very different imaginary resolution to its representation of an endeavour to cure dementia.

Rise of the Planet of the Apes reproduces many of the same tropes and conventions as Deep Blue Sea. The research, this time on captured primates, is driven by the child of a parent with dementia-in this instance, James Franco's Will Rodman, an equally brilliant and driven neuroscientist working for the global pharmaceutical Gen Sys. The laboratory in which he works is also "high tech" and overseen by an acquisitive, profit seeking CEO, Steve Jacobs (David Oyelowo) whose barely concealed brutality matches that of Samuel L Jackson in Deep Blue Sea as does his general habitus and selfish interest in personal enrichment. The science in the film is also characteristically rapid. Like the image of the rapidly firing neurons in Harlin's film and the sudden restoration of Robert Gu's cognitive faculties in Rainbows End, in this film the effects of the treatment are instantaneous and spectacular. Will Rodman is a scientist who runs rather than 
walks down corridors and bursts into rooms rather than communicating his findings by email. The impact of the experimental drugs he trials is immediate and remarkable; after just one dose of the ALZ 112 tested on the primates, his father Charles Rodman (John Lithgow), whose dementia prompts the research, is not only apparently 'miraculously' restored to his former self but improved and enhanced. The film reproduces the popular notion of the rapidity and suddenness of scientific discovery (the 'eureka' moment) and reinforces a promissory investment in the transformative powers of neuroscientific research although in this instance, this research ultimately benefits primates rather than humans.

On one level, the film plays out the same scenario as Deep Blue Sea in that the experimentation has an ultimately catastrophic effect on humans. Not only does Will's father regress and die having developed antibodies to the ALZ112, but the primate handler in the research facility Robert Franklin (Tyler Labine) is exposed to the virus contained in the new variant ALZ113, develops respiratory problems and rapidly dies, though not before sneezing all over the Rodman's unpleasant neighbour. The latter's job as a pilot (referred to in the final scene) indicates the global transmission of the deathly virus through transportation links and serves as a harbinger of the decimation of the human race. However, in contrast to the depiction of the predatory sharks in Deep Blue Sea, the film demands sympathy for the cognitively enhanced primates and explains and accounts for instances of aggression towards their human captors. For instance, the mother of Caesar, the future leader of the apes, attacks the handler to protect her baby and Caesar (who is adopted by Rodman following the killing of his mother) attacks Rodman's neighbour to protect Charles. This is in marked contrast to the depiction of the 'super sharks' as intrinsically and motivelessly malign in Harlin's film.

It is notable that Wyatt's film foregrounds the continuities between the incarceration of the primates in the research facility and the so-called 'primate sanctuary' to which Caesar is sent following his attack on the Rodman's neighbour. The latter, overseen by John Landon (Brian Cox) and his cartoonishly cruel son Dodge (Tom Felton) encapsulates the disjunction between public face and private reality in the bleak, locked cells that lie behind the capacious play area of the 'sanctuary'. Redolent of images of Abu Ghraib, the dark and dirty cells are places of torture and brutality in which the primates are physically and verbally abused by their sadistic captors. This space reproduces the carceral space of the research facility, the intellectual and financial capital of which is predicated upon the use of primates as disposable research subjects, conduits for the accumulation of wealth and prestige on the part of their human captors. The ease with which Steve Jacobs makes the decision to kill all the captive chimpanzees following Caesar's mother's rampage through the facility emphasises the systemic violence that characterises the history of medical research (Lock, 2000, pp 271-272) and the use of vulnerable and powerless research subjects: not just the body of primates but the bodies of the poor, of prisoners, of the enslaved, of racial and religious minorities, and of the disabled.

In drawing attention to the violence that underpins the profit motives of pharmacological corporations such as Gen Sys, the narrative thus exposes the asymmetrical power relations and the inequalities that facilitate the production of medical research, the development of new treatments, their unequal distribution and the role of these institutions and practices in reinforcing inequalities. Significantly, it offers a very different denouement to that of Deep Blue Sea and Rainbows End in the form of the rebellion of the incarcerated primates led by Caesar. In contrast to the destruction with which Deep Blue Sea ends or the lack of transformation in Vinge's novel, here the inequalities that separate research subjects from research beneficiaries are overturned by the collective endeavour of the apes. In marked contrast to the individualism and self-interest that motivates both Jacobs and indeed Rodman (whose intent is primarily to treat his father), the primates work together and are prepared to sacrifice themselves in order to achieve freedom and a "home" for the collective in the forest outside the city. In this particular contribution to the Planet of the Apes franchise, the future lies with communitarian endeavour and resistance to the brutal logic of capitalist accumulation. Much like the properly utopian notion of transformation identified in earlier Hollywood movies by Jameson, the success of the collective resistance of the apes allegorises the impossibility of resolving questions of human value, ageing, resource allocation and futurity in terms of the present neoliberal parameters of markets and individualisation as represented in Deep Blue Sea and Rainbows End. In other words, social change and utopian promise cannot be found within the dominant ideological and economic paradigms of the present; the neoliberal version of a future that solves the question of human value and the crisis of ageing simply isn't working.

\section{Conclusion: regeneration, futurity and persistence}

This essay advances three main arguments. Firstly, that contemporary debates about ageing and dementia are increasingly bound up with the promissory discourses of bio-gerontology and neuroscientific epistemologies that facilitate an imaginative investment in the idea that ageing and age-related conditions such as dementia might be 'defeated'. At the heart of these claims is a model of health and wellbeing that extols the virtues of the independent, economically active and implicitly able-bodied person and repudiates physical frailty, dependence and need in later life. Secondly, I argue that the rhetoric of crisis regarding ageing and dementia is increasingly bound up with the neoliberal reduction of human value to economic productivity and the logic of neoliberal marketization. In relation to the latter, I am referring to the notion that an investment in biotechnology will yield the solution to the resources crisis with which dementia presents us in the shape of lost productivity and the disruption of the flows of capital. The promise of medical regeneration in this sense cannot be extricated from the idea of economic regeneration, the latter being suffused by the notion that eradicating dementia and defeating ageing will address the resource crisis and economic abyss with which an ageing population presents us. Thirdly, I suggest that through an engagement with contemporary popular literature and film and the contradictions and imaginative limits of their narratives, we can perhaps begin to acknowledge the ideological limitations of the neoliberal discourses that circumscribe the ways in which we currently understand dementia and our imaginative investments in the promise if its cure.

What is not accounted for in the postulation of global pharma and the market as the solution to our woes is the intractable problem of how we might address the needs of an ageing population living in the chronic mode. The point here is that despite the apocalyptic narrative that posits dementia as the greatest threat to humanity, curing dementia will not 'cure' ageing or the fact of our mortality despite the confidence of the supporters of indefinite life extension assembled around figures such as Aubrey de Grey. Nor does this narrative of impending resource crisis (and the aligned idea that curing dementia will address it) address the economic implications of large populations of people, displaced by machines and robots, who are not engaged in work or the production of surplus value. What I hope my reading of the cultural texts indicates is that neoliberal theoretical and economic paradigms cannot begin to articulate a response to these problems, they can only displace or avoid them. Indeed, despite the 
discourse of regeneration and attendant notions of futurity, what is perhaps interesting to reflect upon in conclusion is what is left or what remains once we become aware of the limitations, contradictions and failures of this promissory vision of cure in both medical and economic terms. What remains or what persists and what is often elided or not said are important and profoundly difficult questions about our attitudes towards ways of dying, the embodied and affective consequences of impairment and the possibilities of living well with a chronic or terminal condition. As my argument regarding the collective and properly transformative resolution of Rise of the Planet of the Apes makes clear, I would argue that it is only by imagining very different ways of living and working and caring for each other that we can begin to address the implications and possibilities afforded us by the promise of cure or neural regeneration.

Received: 19 July 2017 Accepted: 22 November 2017

Published online: 21 December 2017

\section{Notes}

1 Examples include the three works I discuss here and novels such Jeffrey Moore's The Memory Artists (Moore 2007) or Alexander Jablokov's short story, 'living will' that explores the notion that our memories might be downloaded (Jablokov 1994).

\section{References}

Agamben G, Emcke C (2001) Security and terror. Theory Event 5(4). https://doi. org $/ 10.1353 /$ tae. 2001.0030

Ayo N (2012) Understanding health promotion in a neoliberal climate and the making of health conscious citizens. Crit Public Health 22(1):99-105

The Brain Preservation Foundation (2017) The brain preservation foundation. http://www.brainpreservation.org/. Accessed 2 July 2017

Burke L (2015) The locus of our disease: narratives of family life in the age of Alzheimer's. In: Swinnen A, Schweda M (eds) Popularizing dementia: public expressions and representations of forgetfulness. Bielefeld, Transcript, $\mathrm{p}$ 23-42

Cazdyn E (2012) The already dead: The new time of politics, culture, and illness. Duke University Press

Cooper ME (2011) Life as surplus: Biotechnology and capitalism in the neoliberal era. University of Washington Press

Davis M (2006) Planet of slums. New Perspect Q 23(2):6-11

Dyer-Witheford N (2010) Digital labour, species-becoming and the global worker. Ephemer 10(3):484-503

The ELPIs Foundation for Indefinite Lifespans (2017) The ELPIs Foundation for Indefinite Lifespans. Larnaca, Cyprus. http://elpisfil.org/. Accessed 1 July 2017

Fight Aging (2017) Fight Aging! Austin, TX. https://www.fightaging.org/ introduction/. Accessed 30 June 2017

Fleischer TE (1999) The personhood wars. Theor Med Bioeth 20(3):309-318

Frank T (2007) What's the matter with Kansas? how conservatives won the heart of America. Metropolitan Books

Furedi F (2006) Culture of fear revisited. Continuum, A\&C Black

Gabbard D (2008) Global economy. Knowledge and power in the global economy: The effects of school reform in a Neoliberal/Neoconservative Age, Routledge, London, pp 91-100

Galvin R (2002) Disturbing notions of chronic illness and individual responsibility: towards a genealogy of morals. Health 6(2):107-137

George DR, Whitehouse PJ, Ballenger J (2011) The evolving classification of dementia: placing the DSM-V in a meaningful historical and cultural context and pondering the future of "Alzheimer's". Cult Med Psychiatry 35 (3):417-435

Grey AD, Ames BN, Andersen JK, Bartke A, Campisi J, Heward CB, McCarter RJ, Stock G (2002) Time to talk SENS: critiquing the immutability of human aging. Ann NY Acad Sci 959(1):452-462

Grey ADd (2006a) Is SENS a farrago? Rejuvenation Res 9(4):436-439

Grey ADd (2006b) SENS survives the challenge: now let's get to work. Rejuvenation Res 9(4):429-430

Harlin R (1999) Deep blue sea. Warner Bros, 1999

Harvey D (2007) A brief history of neoliberalism. Oxford University Press, USA

Horkheimer M, Adorno TW (2001) The culture industry: enlightenment as mass deception. In: Durham MG, Kellner DM (eds) Media and cultural studies keyworks. Blackwell, p 71-101
Jablokov A (1994) Living will. In: The breath of suspension. Arkham House Publishers Inc., Sauk City, Wisconsin, pp 53-72

Jameson F (1979) Reification and Utopia in mass culture. Social Text 1:130-148 Jameson F (2003) Future city. New Left Rev 21:65

Jameson F (2013) The political unconscious: narrative as a socially symbolic act. Routledge.

Jeste DV, Alexopoulos GS, Bartels SJ, Cummings JL, Gallo JJ, Gottlieb GL, Halpain MC, Palmer BW, Patterson TL, Reynolds CF (1999) Consensus statement on the upcoming crisis in geriatric mental health: research agenda for the next 2 decades. Arch Gen Psychiatry 56(9):848-853

Kaufman S (2006) Dementia-near-death and life itself. AL Cohen, Thinking Dementia 23-42

Kirkwood T (2002) Molecular gerontology. J Inherit Metab Dis 25(3):189-196

Kirkwood TB (2005) Understanding the odd science of aging. Cell 120(4):437-447

Kirkwood TB, Cremer T (1982) Cytogerontology since 1881: a reappraisal of August Weismann and a review of modern progress. Hum Genet 60 (2):101-121

Kitwood T (1989) Brain, mind and dementia: with particular reference to Alzheimer's disease. Ageing Soc 9(1):1-15

Kitwood T (1990) The dialectics of dementia: With particular reference to Alzheimer's disease. Ageing Soc 10(2):177-196

Kivipelto M, Ngandu T, Fratiglioni L, Viitanen M, Kåreholt I, Winblad B, Helkala E-L, Tuomilehto J, Soininen H, Nissinen A (2005) Obesity and vascular risk factors at midlife and the risk of dementia and Alzheimer disease. Arch Neurol 62(10):1556-1560

Kivipelto M, Solomon A, Ahtiluoto S, Ngandu T, Lehtisalo J, Antikainen R, Bäckman L, Hänninen T, Jula A, Laatikainen T (2013) The Finnish geriatric intervention study to prevent cognitive impairment and disability (FINGER): study design and progress. Alzheimer's Dement 9(6):657-665

Klein N (2007) The shock doctrine: The rise of disaster capitalism. Macmillan.

Lafontaine C (2009) Regenerative medicine's immortal body: From the fight against ageing to the extension of longevity. Body Soc 15(4):53-71

Leibing A, Cohen L (2006) Thinking about dementia: culture, loss, and the anthropology of senility. Rutgers University Press.

Lin S-Y, Lewis FM (2015) Dementia friendly, dementia capable, and dementia positive: concepts to prepare for the future. Gerontologist 55(2):237-244

Lock M (2000) The quest for human organs and the violence of zeal. In: Das V (ed) Violence and Subjectivity. University of California Press, p 271-295

Macdonald A, Cooper B (2006) Long-term care and dementia services: an impending crisis. Age Ageing 36(1):16-22

Methuselah Foundation. Methuselah Foundation. 8021 flint street, springfield, va 22153 https://www.mfoundation.org/, Accessed 10 July 2017

Monbiot G (2016) Neoliberalism-the ideology at the root of all our problems. The Guardian 15(04)

Moore J (2007) The memory artists. Macmillan

Moreira T, Palladino P (2008) Squaring the curve: The anatomo-politics of ageing life and death. Body Soc 14(3):21-47

Moreira T, Palladino P (2009) Ageing between gerontology and biomedicine. BioSocieties 4(4):349-365

Nathan I (2000) Deep blue sea review. Empire. http://www.empireonline.com/ movies/deep-blue-sea/review/. Accessed 28 June 2017

Peel E (2014) 'The living death of Alzheimer's' versus 'Take a walk to keep dementia at bay': representations of dementia in print media and carer discourse. Sociol Health Illn 36(6):885-901

Pellissier J (2007) La guerre des âges. Armand Colin

Rabinow P (2007) Concept work. In: Gibbon S, Novas C (eds) Biosocialities, genetics and the social sciences: Making biologies and identities. Routledge, p 188-192

Ritchie K, Carriere I, Ritchie C, Berr C, Artero S, Ancelin, M-L (2010) Designing prevention programmes to reduce incidence of dementia: prospective cohort study of modifiable risk factors. BMJ 341: c3885

Scott R (1979) Alien.Twentieth Century-Fox, US

Sens Research Foundation (2017) Sens Research Foundation: reimagine aging. 110 Pioneer Way, Suite J, Mountain View, CA 94041, http://www.sens.org/. Accessed 1 July 2017

Shakespeare T, Zeilig H, Mittler P (2017) Rights in mind: thinking differently about dementia and disability. Dementia 1471301217701506

Shelley MW (2014) Frankenstein, or, The Modern Prometheus, 1818. Engage Books, AD Classic

Sinfield A (1992) Faultlines: cultural materialism and the politics of dissident reading. University of California Press

Singer P (1996) Rethinking life and death: The collapse of our traditional ethics. Macmillan.

Spielberg S (1975) Jaws. Universal Pictures, US

Srnicek N, Williams A (2015) Inventing the future: postcapitalism and a world without work. Verso Books

Turner RS (2008) Neo-liberal ideology: history, concepts and policies: history, concepts and policies. Edinburgh University Press

Vinge V (2007) Rainbows end. Pan Macmillan 
Warner H, Anderson J, Austad S, Bergamini E, Bredesen D, Butler R, Carnes BA, Clark BF, Cristofalo V, Faulkner J (2005) Science fact and the SENS agenda. EMBO Rep 6(11):1006-1008

Wyatt R (2011) Rise of the planet of the apes. Twentieth Century Fox Film Corporation, 2011

Zealley B, De Grey AD (2013) Strategies for engineered negligible senescence. Gerontology 59(2):183-189

Zeilig H (2013) Dementia as a cultural metaphor. Gerontologist 54(2):258-267

Žižek S (2010) A permanent economic emergency. New Left Rev 64(1):85-95

\section{Data availability}

Data sharing is not applicable to this article as no datasets were generated or analysed during the current study.

\section{Additional information}

Competing interests: The author declares no competing financial interests.

Reprints and permission information is available online at http://www.nature.com/ reprints
Publisher's note: Springer Nature remains neutral with regard to jurisdictional claims in published maps and institutional affiliations.

(c) (i) Open Access This article is licensed under a Creative Commons Attribution 4.0 International License, which permits use, sharing, adaptation, distribution and reproduction in any medium or format, as long as you give appropriate credit to the original author(s) and the source, provide a link to the Creative Commons license, and indicate if changes were made. The images or other third party material in this article are included in the article's Creative Commons license, unless indicated otherwise in a credit line to the material. If material is not included in the article's Creative Commons license and your intended use is not permitted by statutory regulation or exceeds the permitted use, you will need to obtain permission directly from the copyright holder. To view a copy of this license, visit http://creativecommons.org/ licenses/by/4.0/.

(C) The Author(s) 2017 